\title{
NOTAS SOBRE O PROCESSO URBANO-REGIONAL BRASILEIRO
}

\author{
Sylvio Fausto GIL. FILHO, \\ Professor Assistente - Departamento de Geografia UFPR \\ Mestre em Geografia - UNESP \\ Laboratório de Geografia Humana (LABOHU)
}

Ana Helena Corrèa de FREITAS GIL

Professora - Escola Técnica UFPR

Especialista em Geografia Fisica - UNICENTRO

\section{ABSTRACT:}

The Brazilian Urban-Regional Process under the focus Mercantil Capitalism and the Monopolist industrial Capitalism. Territorial articulation process of the urban fact in Brazil since the structural conceptional in Geography. Spacial implications and historical descontinuations in question since the productize process structured and restructured in Brazil. Redimension Urban Brazilian Net in the historical regional plan and its implications of the urban space production in Brazil.

KEY WOADS: Urban-Regional Process; Urban Brazilian Net; Urban Space in Braziil.

\section{RESUMO:}

Processo Urbano-Regional Brasileiro sob o domínio do Capitalismo Mercantil e Industrial Monopolista. Processo de articulaçăo territorial do fato Urbano no Brasil a partir da concepção estrutural em Geografia. Implicaçōes espaciais e descontinuidades históricas em questão a partir do processo produtivo estruturado e reestruturado no Brasil. Redimensionamento da Rede Urbana Brasileira no plano histórico-regional e suas implicaçōes na produçăo do espaço urbano no Brasil.

PALAVRAS CHAVE: Processo Urbano-Regional; Rede Urbana Brasileira; Espaço Urbano no Brasil. 


\section{INTRODUÇÄO}

O presente trabalho deve ser considerado como uma tentativa $e$ compreensão do processo urbano-regional brasileiro a partir da sucessāo de transformaçōes do modo de produçảo capitalista no Brasil.

A melhor sintese que podemos fazer do processo urbano-regional brasileiro é construi-lo no plano histórico a partir de suas respectivas implicaçōes espaciais e sociais

O processo de urbanizaçăo no nosso pais está sob diversas formas, atrelado à economia internacional, asșim como é a expressão concreta de um capitalismo dependente. Desta forma, as diversas estratégias institucionais referendadas pelo Estado nacional visavam e visam a articulaçäo do Brasil com o modelo do capitalismo internacional

Levamos em conta também que o espaço apresenta uma realidade objetiva $\Theta$ é condiçâo básica ás transformaçōes e desenvolvimento do processo urbano. A partir dos pressupostos colocados estruturamos este ensaio do seguinte modo:

A primeira parte discutirá as bases teóricas gerais e a opçăo do trabalho como também apresentará as caracteristicas da urbanizaçăo no contexto do subdesenvolvimento.

A segunda parte apresentará a estruturaçăo do processo urbano-regional considerando sua participação em duas macrofases:

(i) A Macrofase do Capitalismo Mercantil;

(ii) A Macrofase do Capitalismo Industrial Monopolista.

Guardando as devidas proporçôes, não utilizaremos como base de análise consideraçŏes especificas em termos regionais, utilizando um pouco das mesmas, apenas no intuito de sustentar o nosso argumento quando necessário.

\section{2 - APROXIMAÇĀO TEÓRICA}

Delinear as bases teóricas de interpretaçăo da articulação da rede urbana. através do processo urbano regional é uma tarefa que requer o desenvolvimento de alguns pontos básicos e fundamentais.

A maioria dos trabalhos a respeito do tema restringem-se ao âmbito da descriçāo funcional. Consideramos que tentaremos na nossa análise transcender a este entoque, buscando as essenciais absolutas que fornecem diretrizes $e$ revelam a força matriz do processo em questăo.

Ao discutirmos as bases de nossa análise nos reportamos primeiramente ás questōes de método. Como colocamos anteriormente, o espaço possui uma realidade objetiva e esta é condiçâo fundamental ao caráter das transformaçōes do processo urbano nacional.

O processo urbano é a expressāo concreta da dinâmica social que vitaliza o espaço. Deste modo, o espaço está sendo considerado como uma totalidade, porém, este fato nāo impede que ao mesmo tempo que observamos esta totalidade, também fragmentamos o espaço em elementos passiveis ao resgate desta mesma totalidade. 
Com base em SANTOS (1985), devem ser considerados os seguintes elementos na explicação do processo urbano em seu contexto espacial.

- Os homens como praticantes do trabalho e sob diversas formas formadores e construtores do fato urbano.

- As instituiçōes e firmas que sāo receptoras dos individuos enquanto membros de uma sociedade, assim, como fornecedores de bens, idéias, serviços, normas e legitimaçōeso

- - meio ecológico que é a base física do trabalho humano $e$ consequentemente o contexto da rede urbana e sua dinâmica social.

- As infra-estruturas que trata-se do trabalho humano materializado e geografizado, aparência concreta da açāo dos elementos anteriores.

$\mathrm{Na}$ medida em que há o desenvolvimento do plano histórico a intercambilidade e a redutibilidade aumentam. Na época atual as funçōes destes elementos dinamizam-se e mudam até ao ponto de se confundirem. Esta dinâmica de intercâmbios aproxima-se da noçăo de totalidade. A rede urbana nos parece ser a expressăo concreta desta acepção teórica. No decurso do avanço no plano histórico notamos como os aspectos funcionam $\ominus$ as conexōes de circulaçāo da rede se intensificam ao ponto de se confundirem no espaço. É neste momento, que resgatamos a totalidade do processo urbano. No entanto, a mera descriçăo desses elementos năo é suficiente, pois năo devemos descurar as interaçōes existentes em termos de diretrizes $e$ as. Há de fato uma interdependência funcional entre os elementos e é esta realidade que torna possivel chegarmos a totalidade sócio-espacial.

A regiăo urbana, na noçăo ampla, é configurada a partir de movimentos circulatórios como capital, de mercadorias e movimentos populacionais. A dinâmica destes movimentos torna possivel a vida de uma sociedade. A energia, também é essencial pois permite a dinâmica, devendo-se lembrar. que as necessidades sāo satisteitas a partir da produção. Deste modo, a transformaçâo do meio ecológico em infra-estruturas através da produçāo é considerado como segunda natureza, já que a primeira natureza tende a ser mais um conceito de que uma realidade concreta na medida em que a sociedade humana se já se apropriou de todo planeta.

O urbano é o locus onde as infra-estruturas ou a segunda natureza atinge o maior grau de complexidade e é perpassando pelas inståncias culturalideológica e politico-institucional. Cabe lembrar que, na medida em que se desenvolve a história, toda e qualquer variável está em transformaçāo constante. Cada elemento em cada momento histórico muda sua posiçăo e sua representação no sistema temporo-espacial.

Recrutamos o papel de um dado elemento espacial em um momento histórico específico, na medida em que retomamos sua relação com os demais elementos. Daí o caráter do elemento se apresenta em sua plenitude quando considera-se a relaçăo com o outro elemento. A análise do fato urbano articula-se nesta perspectiva metodológica. Sob diversas formas quando verificamos sua expansão e reestruturaçăo sob a vigência do capitalismo mercantil e suas grandes mutaçŏes sob o capitalismo industrial monopolista da atualidade. É por esta razão que devemos considerar os elementos como variáveis pois modificamse quantitativarnente $e$ qualitativamente acoplado ao transcorrer do processo histórico. 
A importåncia do valor do elemento no espaço possui variaçōes segundo o lugar onde se processa. Assim quando se toma o fato urbano a partir da análise dos elementos leva-se em consideração a variaçâo locacional e temporal. Quando verificamos a processo urbano a partir das variáveis localizadas acentuase o caráter especifico de cada lugar.

No presente ensaio considerar-se-á o homem enquanto ser social, com função especifica e diferenciada, $\theta$ o seu relacionamento com os demais elementos.

O urbano está relacionado, em sua dinâmica, ao elemento técnica o qual redimensiona a ação do capital no espaço. A evolução técnica possui caráter diferenciado em cada momento histórico. Assim, a expansão urbana está sob vários aspectos, ligada a capacidade técnica de transformaçăo concreta do espaço. A descontinuidade de implementaçăo das técnicas em períodos históricos diferenciados revelam, quando concretizadas no espaço, as disparidades regionais da realidade da estrutura urbana.

A organizaçāo são as normas que regem as variáveis, é o que fornece o vigor $e$ a realidade da funçāo.

Segundo SANTOS(1985) :

"É na medida em que a economia se complica que as relaçōes entre variàveis se dăo, não apenas localmente, mas a escalas espaciais cada vez mais amplas. O mais pequeno lugar, na mais distante fraçăo do território, tem, hoje, relaçōes diretas ou indiretas com outros lugares de onde the vêm materia-prima. capital, mão-de-obra, recursos diversos e ordens. Desse modo, o papel regulador das funçōes locais tende a escapar, parcialmente ou no todo, menos ou mais, ao que ainda se poderia chamar de sociedade local, para cair nas mâos de centros de decisão longinquos e estranhos às finalidades próprias da sociedade local." (p.13)

A concepçáo estruturalista apresentada considera que a estrutura é dirigida pelo modo de produção dominante adaptado ao meio local. Podemos asseverar que as relaçōes das variáveis podem ser de caráter simples ou de caráter giobal. Tal fato vem de encontro ao processo de urbanização envolver diretrizes de caráter local, nacional e supranacional, na medida em que a escala reflete a própria ação seletiva do capital.

Quando observarmos a dinåmica do capitalismo mercantil no Brasil, verificamos a expansăo da produção e a implantação de certas infra-estruturas de circulaçăo. No entanto, a criaçăo de cidades relaçiona-se a um espaço produtivo intimamente ligado às possibilidades do meio natural e a capacidade têcnica limitada. 
$\mathrm{Na}$ fase do capitalismo industrial monopolista verifica-se uma capacidade altamente complexa de exploração e superaçăo do meio natural. As vias de transportes construidas e as redes de comunicaçăo retratam esta realidade. Pontos privilegiados do espaço foram, desta forma, articulados às cidades de maior porte do Brasil.

Observamos um novo patamar na divisão internacional do trabalho relacionado as novas dimensôes da produçâo. $A$ totalidade do espaço passa a ser nāo mais uma pura acepção teórica, mas sim, uma realidade concreta, principalmente no que diz respeito ao urbano. Este caráter mundializado do fenômeno urbano vai ao encontro das premissas antes levantadas.

O território passa a ter em contrapartida ao caráter mundializado. caracteristicas cada vez mais específicas em relação a produção, com descontinuidades regionais mais acentuadas. O Brasil é reflexo desta nova dinàmica do capital, cuja açăo, nos revela os profundos contrastes regionais de nosso pais.

Segundo SANTOS (1985):

"Podemos falar de uma nova forma de urbanização e de novas hierarquias urbanas, função do tato de que a circulaçāo entre as cidades interessa a diversos daqueles do periodo anterior. Agora, a circulaçáo de ordens, de mais-valia, de informaçāo, passam ao primeiro plano e se sujeitam a uma hierarquia calcada sobre necessidades que são próprias da cidade ou de regiōes agricolas circundantes, mas que refletem relaçōes menos "naturais". Antes, a circulação era praticamente apenas de produtos. A produção local que ia alimentar a indústria $e$ a populaçāo de cidades maiores, dentro ou fora do pals, constituía o essencial da atividade urbana, a qual presidia o seu comercio. Hoje, graças ao desenvolvimento dos transportes, boa parte desse comércio pode ser feito diretamente, em direçẫo às grandes cidades, mas, segundo os casos, a atividade produtiva tem uma demanda importante de acessoramento industrial, financeiro, jurídico, etc, que dota as cidades de um novo conteúdo. Essa tendencia é tanto mais nitida quanto maior a quantidade de capitais fixos envolvidos na produção. Pelo fato de que aumentar o capital fixo significa que a produção necessita, em maior numero, de insumos cientificos," (p.40)

A temática de maior aplicabilidade a fim de revelar a revoluçẩo urbana do Brasil refere-se ao estudo da rede urbana redinamizada pelos nexos da técnica e informaçăo. 
No entanto, não podemos apenas nos limitarmos ao estudo de teorias funcionais, como por exemplo, a Teoria dos Lugares Centrais de Christaller que, embora possa nos dar as diretrizes básicas da disposiçăo funcional da rede urbana, não revela com propriedade a cidade e, como extensăo, a rede urbana. o palco das dinâmicas sociais, marcadas de conflitos $\theta$ antagonismos.

O elemento-pivố do processo, como colocado anteriormente, é o homem que no conteúdo social produz e reproduz as formas espaciais. Para prover uma maior identificação da rede urbana nos baseamos em CORRÊA (1989). Primeiramente, a dimensāo da divisão territorial do trabalho, em seguida as relaçōes entre a expansāo do fato urbano $\theta$ o processo de exploraçāo econômica no Brasil e como sintese as relaçōes entre o fato urbano territorialmente articulado e as formas espaciais a partir das macrofases já identificadas.

\section{3 - URBANIZAÇĂO NO CONTEXTO DO SUBDESENVOLVIMENTO}

Consideramos que o subdesenvolvimento possui caracteristicas comuns em várias partes do globo, sendo uma delas as relaçōes de dependência, como é o caso brasileiro.

Muitos paises acham-se até hoje, atrelados às dividas externas e a açăo do capitalismo industrial monopolista internacional. É neste contexto, que inserese o processo de urbanização, expansāo e o crescimento do urbano.

O destaque especifico do processo de urbanizaçăo, esta relacionado em princípio, com base em SANTOS(1985), aos elementos de modernizaçăo presentes durante o periodo de comércio em grande escala. O que as cidades latino-americanas possuem como caracteristicas peculiares está relacionado ás necessidades de intercâmbios e ao consequiente contato com os elementos de modernizaçāo de cada época. Sob os ditames do capitalismo mercantil. constituiu-se as bases do subdesenvolvimento, ou seja, as relaçōes de dominação da época que foram os desequilibrios sociais e económicos que se reproduzem hodiernamente.

As cidades do periodo colonial săo eminentemente costeiras espelhando a realidade das conveniências do capitalismo mercantil português,

Como coloca SPOSITO (1988):

"Os estados Nacionais Absolutistas desenvolveram sua açăo politica numa segunda frente, muito importante para o processo de urbanizaçăo. A necessidade de ampliar as condiçóes para o desenvolvimento do capitalismo impulsionou o empreendimento de grandes navegaçōes maritimas. Promovia-se com isso a expansão colonial e a criaçâo de novos monopólios comerciais. Este processo de reforço â economia mercantil permitiu a extensão da urbanizaçăo ao mundo colonial, a partir do século $X V$. Ainda que as primeiras cidades coloniais năo tenham sido mais do que portos construidos para escoar riquezas coloniais em exploração, ou fortes para 


\begin{abstract}
proteger os colonizadores, a extensẩo do fato urbano a novas áreas foi importante, porque se constitui no embrião de um processo de ampliaçăo espacial da urbanizaçăo e no suporte de articulação destas novas àreas ao capitalismo mercantil europeu. À medida que - proprio capitalismo se desenvolvia, esta urbanizaçäo no mundo colonial..., for se ampliando e tomando um caráter de multiplicidade funcional ( $p .39)$
\end{abstract}

As cidades brasileiras estavam relacionadas ao caráter funcional da época a partir de sua articulação com a Metrópole.Colonial. Ou seja, eram as cidades os centros comerciais da expansāo agricola que ocorria no Brasil. Mais tarde, a exploraçäo mineira que resultou em um caráter mais interiorano, até a posterior expansão industrial, que generalizou o processo.

O compasso do processo de urbanizaçăo sob o manto do capitalismo mercantil era intermitente, onde havia um ajustamento ao modelo europeu. A cidade já aparecia como locus dos conflitos sociais, que brotavam em palco eminentemente urbano $e$ a estratificação de classes ainda era polarizada.

O fato das grandes cidades latino-americanas serem anteriores ao desenvolvimento industrial $\theta$ dos transportes caracterizou uma organizaçăo do espaço em escala nacional e regional năo necessariamente atreladas a esses melos, como foi o caso em outros paises coloniais da África e Ásia. No entanto, o advento das infra-estruturas de transportes modificou a importância destas cidades e foram pontos fundamentais relativos a dinâmica territorial urbana brasileira. Os velhos centros econômicos foram revitalizados como surgimento do capitalismo industrial no pais. A dinâmica urbana brasileira revelou aptidão a industrialização que processou-se em uma época de transiçăo entre os anos 20 • 30 sob a supremacia do capitalismo industrial monopolista, assim como a grande intervençāo estatal.

Assim como SANTOS (1982), podemos caracterizar as cidades brasileiras sob o manto do capitalismo mercantil, como pontos próximos às áreas de produçăo, que possuiam e que facilitavam os transportes. Esta situaçăo. aumentava a produtividade da rede, como também levava a uma maior acumulaçäo de recursos. O que se pode concluir é que a atividade agrícola permitiu uma melhor distribuiçăo do fato urbano do que a atividade mineira. No entanto, a atividade mineira permitiu um grande incremento econômico na cidade e fora dela, proporcionando um aumento populacional e do número de empregos. A cidade torna-se um lugar de comerciantes, residência de agricultores $e$ funcionários da colönia.

$\mathrm{Na}$ fase do capitalismo industrial monopolista o papel do Estado fol fundamental no estabelecimento de uma nova ordem económica. Dispondo de um complexo institucional e com forte suporte financeiro o estado proporcionou a maturaçăo da modernização do pais no pós $2^{a}$ Guerra Mundial. Praticamente os processos mecânicos de superação das condiçôes naturais $\theta$ a modernização redimensionaram a articulaçảo territorial urbana e condicionaram uma nova hierarquia diferenciada de momentos históricos anteriores. 


\title{
4 - O PROCESSO URBANO-REGIONAL BRASILEIRO NA MACROFASE DO CAPITALISMO MERCANTIL
}

As cidades brasileiras foram fundadas e cristalizaram-se na costa oriental da América. A princípio constituiam-se em pequenas feitorias e também como ponto de apoio ao reconhecimento e afirmação de posse do tráfico do poder colonial português.

Segundo BASTIDE (1978):

\begin{abstract}
"Já se tem dito que a formação do Brasil foi 'ganglionar'. Existiram efetivamente no principio da colonização, quatro centros principais de povoamento, todos localizados no litoral, mas extremamente distanciados uns dos outros, comunicando-se apenas pelo mar; Maranhāo, Pernambuco, Bahia e Sāo Vicente. Células primordiais que se multiplicarăo, dando nascimento, ao seu redor, a outras células, até que todas acabam por se encontrar, formando o Brasil. Durante largo tempo, porém, o país năo terá apenas a unidade, mais ficticia do que real do governo-geral, $\theta$ compor-se-á apenas destas lihotas de população." (p.26)
\end{abstract}

Até que ponto podemos considerar os agiomerados do periodo colonial como cidades é duvidoso. No entanto, nảo esquecemos o fato de que a dinâmica considerada urbana nesta fase do capitalismo mercantil, é verificada nestes povoados. Consideramos assim esses aglomerados como protótipos das cidades pós revoluçăo industrial.

O fato urbano de características eminentemente costeiras no Brasil fol por longo tempo exclusivo e expressava o interesse e a margem de lucro do mercantilismo europeu.

Como afirma MARX M.(1980):

"As primeiras fundaçőes se fizeram no fitoral para sua ligação com a metrópole lusitana e com o resto de um imperio voltado, conformado e cimentado pelo mar. Por isso, o porto foi essencial e decisivo para situar uma feitoria nova. Depois, a necessidade de o defender impós determinados acidentes geográficos, como uma elevaçäo em Porto Seguro ou uma liha em Itamaraca. A preocupaçăo com a defesa $e$ a busca são condiçōes topográficas especiais Săo testemunhas, tambem no interior, pela implantaçăo de São Paulo e Piratininga.( p. 19) 
Já evidenciamos que na medida em, que se desenvolve o processo econômico brasileiro a dinàmica e a estrutura da rede urbana esta intimamente a ele ligada. Até a escolha do sitio urbano por parte da coroa portuguesa fundamentalmente visava proteger os interesses do mercantilismo portugués.

No periodo colonial e do império, a economia urbana ainda era frágii, excluídos alguns poucos centros de exportação onde o número de habitantes e a acumulaçăo e de capital tornava-se notável. Na maior parte do território havia centros urbanos de base econômica agricola, sede de um comércio interno quase inexpressivo e de algumas atividades artesanais. Também podemos nos referir a funçāo administrativa desses aglomerados iniciais assim como a militar.

PRADO JÚNIOA (1956) comenta que os aglomerados urbanos da época eram extensōes do meio rural. Quase a totalidade dos habitantes eram pessoas ligadas direta ou indiretamente ao campo. Havia poucos comerciantes que também eram fazendeiros e formavam uma populaçăo marginal. Com o desenvolvimento das agiomeraçōes as funçōes tornaram-se mais complexas e especificas, havendo uma separação mais clara entre a populaçăo urbana e a populaçăo rural. Surgem instituiçōes administrativas e politicas fixas. Porém, a hegemonia da classe rural predominava na politica e na economia que se configurava.

As condiçōes do campo foram as diretrizes para a cidade, através da classe dominante urbana que de lá provém.

GEIGER(1963), coloca que a modificação da estrutura agrária, imposta pela abolição da escravatura no fim do século XIX, proporcionou uma nova divisão do trabalho. No Centro-Sul formava-se pequenos e médios aglomerados urbanos a partir da migração européia. Estas transformações marcarão profundamente o desenvolvimento da rede urbana brasileira que nos fins do século assumiu um estado de pleno desenvolvimento, contrário à letargia que se verificava anteriormente.

Verifica-se áreas novas mais interioranas como o oeste paulista $\Theta$ o norte do Paraná, pioneiras da economia cafeeira. Estas áreas prósperas de nova acumulaçăo de capital caracterizaram o patamar das-cidades médias na hierarquia da rede urbana nacional que se configurava. Os principais núcleos urbanos do período colonial săo dinamizados nesta fase sucessiva.

A dinâmica das cidades sob o capitalismo mercantil caracterizam-se pela produçâo voltada para o exterior e ciclos de exploraçăo econômica de caráter efêmero.

O período da mineraçã̃o deixou algumas marcas notáveis em relação ao fato urbano. Segundo PRADO JÜNIOR (1969:): 
"A relativa simplicidade da estrutura social brasileira no século e meio do descobrimento se complica na segunda metade do século XVII, com o aumento da riqueza $\theta$ desenvolvimento económico do Pais, pela intromissão de novas formas económicas e sociais. Ao lado da economia agricola que até entâo dominava, se desenvolve a mobiliária: o comércio e o crédito. E com ela surge uma rica burguesia de negociantes, que por seus haveres rapidamente acumulados, começa a por em xeque a nobreza dos proprietários rurais, até então a única classe abastada, e portanto de prestigio da colónia. E por obra dela que as cidades do litoral, onde se fixa, se transformam em centros populosos e ricos. Compunha-se esta burguesia quase toda de naturais do Reino... E é ao comercio que se dedicavam de preferência estes novos elementos. Mais tarde derivam em grandes quantidades para as minas..." (pp. 36-37)

A nova dinåmica das cidades proporcionaram um aspecto social, politico $\mathrm{e}$ econômico até então inexistente, ou seja, a formaçăo de movimentos sociais e de uma classe intelectual nativa. Muito da configuraçäo territorial urbana brasileira devern-se à açáo politica do governo português, sendo que estas caracteristicas, embora com modificaçöes sensíveis, sâo mantidas. A abolição da escravatura provocará uma mudança na estrutura agrária e social repercutindo no quadro urbano. Até então a cidade assume o papel mantenedor da politica e economia colonial exportadora, latifundiária e escravista.

MAMIGONIAN (1982) com base em Prado Júnior resume a configuração da rede urbana no periodo colonial:

"O mercantilismo monopolista português necessitava controlar no Brasil uma poucas ... cidades litorâneas, ao mesmo tempo comerciais(...) e politico administrativas (civis e militares). Enquanto o caráter exportador e dominador da colonizaçăo requeria a presença de cidades, o caráter latifundiário e escravista das relações de produção mostrou-se pouco urbanizador (apenas os grandes fazendeiros residiam nas cidades). Esta contradiçăo entre as partes do sistema colonial resolveu-se pelo surgimento de poucas cidades litorăneas grandes ( para a época) cercadas de "rural". Pode-se dizer que a macrocefalia urbana nasceu no Brasil, como decorréncia do monopólio administrativo, comercial e fundiàrio." (p.13) 
Dois aspectos da urbanização brasileira sob o manto do capitalismo mercantil nos parece com nuança. O resgate destas facetas foram tomadas de GEIGER (1963). Em primeiro lugar a herança colonial na estrutura de nossa rede urbana e em segundo lugar as modificaçōes destas caracteristicas após a maior complexidade económica do século XIX e a mudança da sociedade escravista para o de sociedade classista de trabalho assalariado. Além da eminência litorânea da cidade brasileira destacar as repercussōes que a funçăo militar de algumas cidades no que diz respeito a posiçăo e escolha do sítio urbano como já apontamos. A exemplo de Salvador, Florianópolis e Vitória.

Os períodos econômicos que sucederam-se no pais deixaram marcas urbanas, somente a exploração do pau-brasil não referendou este fato. No entanto, a economia açucareira nacional, institulu pontos no território de caráter autônomo ligados a metrópole portuguesa.

Segundo GEIGER (1963):

\begin{abstract}
"A economía açucareira, além de impulsionar o desenvolvimento de portos maritimos, deu origem a outras localidades, nos diversos periodos de expansão do cuitivo da graminea.

Algumas delas surgern como pontos intermediários no transporte do açucar, dos engenhos aos portos de exportação." (p.73)
\end{abstract}

A dinămica da formaçăo dos núcleos urbanos da época dispōe no espaço em fundo de vale e ao longo de rios, vias de transportes naturais $e$, mais tarde ac longo dos caminhos percorridos pêlos tropeiros, intensificando o comércio $\theta$ as fronteiras agricolas. A abolição da escravatura trouxe algumas repercussōes em termos da expansäo urbana.

Segundo DEFFONTAINES (1940):

"A supressāo da escravatura nāo transformou o regime de fazenda; trouxe apenas mudanças de detalhes; em vez de alojar os trabalhadores em senzalas grupadas em torno de pátios fechados, construifram-se verdadeiras cidades operárias rurais, com casas separadas, alinhadas, todas iguais: é a "colônia,", que substitui a senzala." (p.57)

Sob o aspecto estrutural, a urbanizaçăo presa ao capitalismo mercantil monopolista português fundamenta a origem de relaçŏes de dependência que se reproduz sob o manto do capitalismo industrial monopolista, porém, é claro, com outro refino. As transformações do século XIX nos parece como ponto de transição para o que entendemos como o processo de urbanização atual.

GEIGER (1963) comenta que: 


\begin{abstract}
"O século XIX assistiu a uma série de transformaçōes econômicas que tiveram influência na evolução da rede urbana. Logo no inicio a Abertura dos Portos marca a entrada do País na esfera de dependéncia direta das potências industriais; nos seus meados, a abolição do tráfico significou a libertaçåo de capitais para inversŏes em "negócios" ou seja, em atividades relacionadas com o processo urbano, com o seu mercado; por fim, quase ao encerrar-se o século, a Aboliçāo da escravatura, que ativou o mercado de trabalho. (p.79)
\end{abstract}

\title{
5 - O PAOCESSO URBANO-REGIONAL BRASILEIRO NA MACROFASE DO CAPITALISMO INDUSTRIAL MONOPOLISTA
}

Considerar a urbanizaçăo no Brasil sob a hegernonia do capitalismo industrial monopolista relaciona-se diretamente com a questão de fixar o período em que a industrializaçäo estruturou-se. Embora existam muitas descontinuidades na industrializaçăo brasileira, podemos considerar o impulso neste processo, com maior clareza, no $2^{2}$ pós Guerra, No entanto, nos anos 20 e 30 intensificou-se a modernização das principais cidades brasileiras com certa êntase a concentração industrial em algumas áreas, como São Paulo $e$ os insumos adquiridos com o imigraçâo européia no sul do país.

As circunstâncias da crise $1^{\text {* }}$ pós Guerra e a depressầo norte-americana de 1920, forneceram algumas condiçōes para a intensificação das indústrias no Brasil. A partir da acumulação de recursos provindos da produçăo cafeeira e a transferencia destes para as cidades formou-se o excedente base para o desenvolvimento industrial. Porém, não podemos asseverar que houve a formaçăo de um verdadeiro capitalismo industrial neste periodo; o que nos remete a premissa anterior do $2^{\circ}$ pós Guerra.

No entanto, a vinculaçāo direta da urbanizaçāo nẫo nos parece totalmente satisfatória.

Conforme SANTOS (1982):

"Há muito se vem tentando estabelecer uma relaçāo entre urbanizaçāo e industrializaçăo, considerada esta última simultaneamente num sentido mais amplo, levando-se em conta o que ocorreu nos paises atualmente desenvolvidos. Com efeito, pode-se indubitavelmente constatar um certo paralelismo na evoluçăo desses paises. Até mesmo a defasagem do fenômeno da industrialização entre diversos países coincide com a defasagem de sua urbanizaçăo. 
É dificil estabelecer relaçōes tẩo sistemáticas nos paises subdesenvolvidos, pois neles temos de lidar com pelo menos três dados: modernizaçăo, industrializaçầo e urbanização. A modernizaçăo, fenómeno reflexo das transformaçóes dos paises mais adiantados, pode provocar a urbanizaçāo, sem contudo criar uma industrialização imediata." ( $p .55)$

Resgatando a perspectiva histótica, um ponto fundamental na compreensão da afirmação do capitalismo industrial monopolista no Brasil esta ligado de certa forma a incapacidade que a iniciativa privada nacional tinha em oferecer padrōes de acumulaçăo necessários à nova dinămica industrial. É neste contexto que a intervençáo estatal se faz presente a fim de oferecer condições para a estruturação das bases do desenvolvimento do capitalismo industrial no país. Através de um papel controlador, o Estado, modificou a açāo política em referência às oligarquias agricolas que, até entäo, exerciam o poder político $\theta$ procedeu na implantaçăo de infra-estruturas e politicas viáveis à açāo do capital no espaço nacional. Todavia, a expansāo do capitalismo industrial monopolista năo se fez apenas por açăo do Estado, mas, também, pelas condiçōes no mundo dito desenvolvido que ampliaram o seu espectro para o mundo subdesenvolvido através das transnacionais.

Segundo DAVIDOVICH (1984):

"A barreira enfrentada pelo espaço econômico do capitalismo a nivel mundial no periodo posterior a II Guerra, com a expansâo da economia socialista. Ampliou-se assim o caminho para a industrialização da periferia, agenciada pelos paises centrais, que enfrentavam também o alto custo de sua força de trabalho, e sendo sobretudo de certa dimensão e com determinado patamar de acumulação o Brasil, se tomou uma das areas privilegiadas de expansăo da empresa transnacional. Os anos 50 e 70 foram os de inversão diretas mais vultuosas de corporaçōes estrangeiras." (p.13)

A açāo do estado nesta fase articulado com as grandes empresas transnacionais, foi determinante na industrializaçào e modernizaçăo do Brasil. Este fato caracterizava melhor a fase do capitalismo industrial monopolista. A nova dinâmica implicou na hegemonia do estilo urbano de vida e a expansẫo do setor terciário da economia, que ao nosso entender, dita a expansầo da rede urbana em muitos aspectos. O paico urbano agora torma-se, sem dúvida o centro das funçōes relativas a circulaçāo do capital $e$ das mercadorias. Fortalecendo este ponto esta a localização dos sistemas institucionais e empresas privadas além da organização comercial e industrial neste contexto. 
Segundo PRADO JÚNIOR (1956) a entrada de capital estrangeiro no Brasil em meados do século XX equilibrou as contas externas do pais e proporcionou urn aparelhamento material e uma sensivel progressăo do padrắo de vida nacional. Infra-estruturas portuárias e ferroviárias cresceram rapidamente e especialmente os transportes rodoviários; inauguraram as bases energéticas para a progressão industrial e desenvolvimento urbano.

O advento das classes médias como pivô da expansẫo do estilo urbano de vida é fato relevante desse periodo. A ascensăo das classes médias vai aumentar ainda mais as disparidades de concentração de riquezas do pais na medida em que estas são um apoio ideológico sem precedentes ás classes dominantes.

Com base em DAVIDOVICH (1984), podemos inferir alguris aspectos estruturais importantes neste periodo. Em primeiro lugar a expansäo dos contingentes administrativos impulsionado peio padrăo organizacional das empresas nacionais e transnacionais que foram pontos primordiais da expansão das classes médias. Em seguida, a adoção de um modelo de desenvolvimento para uma modernizaçăo acelerada do pais, porém, imposta pelo poder estatal.

Este modelo gerou uma grande disparidade social na medida em que a massa da populaçăo nâo participou das benesses do processo, que acabou concentrando ainda mais a riqueza nas mãos de poucos.

Segundo PRADO JÚNIOR (1956):

"Em primeiro lugar, o imperialismo atua como um poderoso fator de exploraçāo da riqueza nacional; nẩo é outro seu objetivo que acapachar em proveito próprio a mais valia do trabalho brasileiro ao seu alcance. Nisto ele age como qualquer outra forma de capital e nāo tem al nada de particularmente interessante. Mas o que distingue é que tal exploração não se faz beneficio de uma classe brasileira, uma burguesia indigena (a nāo ser grupos insignificantes ligados diretamente capital financeiro, e tăo internacionais quanto a ele), mas de classes e interesses completamente estranhos no pais. Isto é muito importante, porque neste processo nåo é apenas a classe trabalhadora que se desfalca, mas o país em conjunto que vê escoar-se para fora de suas fronteiras a melhor parcela de suas riquezas e recurso. As contradiçöes da exploraçăo capitalista tomam assim caráter muito mais agudo e extremo. Entre outros efeitos bem patentes estão a deficiência e morosidade da acumulação de capitalista brasileira, essencialmente débil. Falta assim ao pais o elemento fundamental de progresso económico." (p.280) 
O redimensionamento da urbanizaçăo passou pela expansâo cafeeira com sua consequeente acumulação de riqueza e as infra-estruturas decorrentes da açăo do Estado no final do século passado e meados deste século. As condiçóes econômicas que ora se configurava, guiava as diretrizes da expansăo urbana no país. Esta expansăo fol base para a acumulaçăo de capital fixo na cidade que proporcionou condiçōes para a expansão industrial.

O fato que destacamos refere-se a divisão social do trabaiho que a cidade propiciou de modo mais complexo, assim como foi palco da expansăo do mercado interno.

Esta realidade proporcionou a divisão territorial do trabalho na medida em que o fato urbano articulava-se com vantagens locacionais diferenciadas $\mathrm{e}$ com valoraçōes distintas. Assim como a hierarquia urbana pressupōe especificidades funcionais concretas. Desta forma, consideramos a articulaçäo territorial urbana no Brasil como condiçăo para um redimensionamento da divisão espacial do trabalho.

Como afirma CORRÊA (1989):

\begin{abstract}
"A cidade em suas origens constitui-se não só em uma expressăo da divisăo entre trabalho manual $e$ intelectual, como também em um ponto no espaço geográfico que, através da apropriação de excedentes agricolas, passou de certo modo a controlar a produçāo rural. Este papel de condição é mais tarde transmitido à rede urbana: Sua Gênese e evoluçăo verificam-se na medida em que, de modo sincrónico, a divisāo territorial do trabalho assumia progressivamente, a partir do século XVI, uma dimensăo mundial." (p.49)
\end{abstract}

Quanto a configuraçăo da urbanização em termos territoriais observamos que o maior crescimento populacional se deu na regiāo Sudeste. Esta regiảo foi o locus principal do processo de urbanização do pais assim como, a maior concentraçāo da açăo empresarial do Estado e dos setores privados nacionais e transnacionais:

O periodo de 1939 a 1960 caracterizou-se pelo desenvolvimento de bens de produçăo centrados na porção Centro-Sul do pais.

GEIGER (1963) comenta que:

"Capitais estrangeiros passam a interessar mais pela produção industrial no Brasil e todas as circunstăncias se conjugavam em prol da concentração no Centro-Sul. Ai era mais tucrativo instalar industrias, principalmente em Sāo Paulo que ganhará a fama de dispor de mäo de obra mais eficiente. As grandes metrópoles, como Rio de Janeiro e Săo Paulo, ampliam seu espaço urbano, englobam novos subúrbios. 
Em Belo Horizonte e Contagem aparece como satélite industrial. Grande parte do incremento da população urbana observado entre os recenseamentos de 1940 e 1950 deve-se à evoluçāo industrial inclusive - gigantismo crescente das duas metrópoles nacionais." (p.439)

O incremento da cabeça da hierarquia da rede urbana brasileira redimensionou as metrópoles regionais da região Sul que sofreram um desenvolvimento industrial a partir da imigraçăo européia e agora sofriam as consequêencias desta expansăo.

A década de 1970 a 1980 demonstrou uma aceleraçăo sem precedentes no processo de urbanização do país.

Segundo DAVIDOVICH (1984) : "Na última década,.., o crescimento urbano mostrou-se ainda importante, apresentando uma taxa de $4.5 \%$ ao ano que suplantou por larga margem a de um incremento nacional da populaçäo da ordem de $2,5 \%$ anuais". (pp. 19-20)

A metropolização e a maior articulaçăo na rede urbana com centros médios e centros mais distantes do território engendrados pelo Estado săo caracteristicas marcantes da urbanizaçāo brasileira no período recente.

Esta realidade tende a uma totalidade no sentido em que envolve mudanças de caráter sócio-espacial rompendo as limitaçōes especificamente regionais e promovendo um redimensionamento da estrutura social do pais. Estamos diante do reflexo das características e da dinâmica do capitalismo industrial monopolista estruturado do pais.

\section{CONSIDERAÇŌES FINAIS}

Ao elaborar as diretrizes do presente trabalho colocamos algumas premissas iniciais:

(i) asseveramos as relaçōes econômicas de dependència $\theta$ a conseqũente intervenção do capital estrangeiro na realidade económica brasileira, assim como, a açāo do Estado viabilizando o modelo do capitalismo industrial monopolista;

(ii) em seguida, resgatamos o espaço como categoria de análise búsica a estruturaçăo urbano-regional.

Acreditamos que a opçăo de análise da reestruturaçāo urbana a partir das duas macrofases ou seja, o capitalismo mercantil e o capitalismo industrial monopolista, proporcionou um resgate, embora parcial, de uma interpretaçāo da articulaçăo territorial do fato urbano brasileiro. Resgatamos também a açăo institucional como desencadeadora e viabilizadora do processo em questâo.

Para finalizar, consideramos o urbano como locus da açăo social e ideológica por excelência. Tanto quanto a história do pais é o resgate da açăo de idéias brotadas no meio urbano, A realidade urbana atual reflete as marcas do processo de colonizaçảo e sua expansảo expressa as contradiçő́es do modo de produçäo capitalista. 
REFERÊNCIAS BIBLIOGRÁFICAS

BASTIDE, Roger. Brasil, Terra de Contrastes. Sāo Paulo: Difet, 1978.

CORRÉA, Roberto Lobato. A Rede Urbana. São Paulo: Ática, 1989.

DAVIDOVICH, Fanny. "Urbanizaçăo Brasileira: Tendências, Problemas e Debates." Espaço e Debates, Săo Paulo: IPPUA (13), 1984.

DEFFONTAINES, Pierre. Geografia Humana do Brasil. Rio de Janeiro: IBGE, 1940.

GEIGER, Pedro P. A Evoluçăo da Rede Urbana Brasileira. Rio de Janeiro, MEC, 1963 ,

MAMIGONIAN, Armem. "Notas sobre a geografia urbana Brasileira." In SANTOS, M. Novos Rumos da Geografia Brasileira. São Paulo: HUCITEC, 1982.

MARX, Murilo. Cidade Brasileira. Sāo Paulo: Melhoramentos \& EDUSP, 1980.

PRADO JÚNIOR, Caio. Formaçāo Política do Brasil e outros Estudos. Săo Paulo: Brasiliense, 1969.

História Econômica do Brasil. Sāo Paulo: Brasiliense, 1956.

RIBEIRO, Ana Clara Torres. "O Fato Metropolitano-Espaço e Sociedade." in SANTOS, M. \& SOUZA, M.A., A Construção do Espaço. São Paulo: Nobel, 1986.

SANTOS, M. Ensaios sobre Urbanização Latino-Americana. Săo Paulo: HUCITEC, 1982.

Espaço e Método. Săo Paulo: Nobel, 1985.

Manual de Geografia Urbana. Săo Paulo: HUCITEC, 1989. 
SHORT, J.R. The Urban Order. Oxford: Blackwell, 1996.

SPOSITO, Maria E.B. Capitalismo e Urbanização. São Paulo, Contexto, 1989. 